\title{
Effect of CD34+ Stem Cell Injection and Their Mobilization from Bone Marrow by Granulocyte-Colony Stimulating Factor in Regeneration of Myocardium after Experimental Induction of Acute Myocardial Infarction in Adult Albino Rat
}

\author{
Gamal M. A. Hassan (l), Yasser M. El-Wazir(2), Nermin S. Ahmed (l) and Amira E. E. Farage(l)
}

Departments of Anatomy ${ }^{(1)}$ and Physiology ${ }^{(2)}$, Faculty of Medicine, Suez Canal University, Ismailia, Egypt

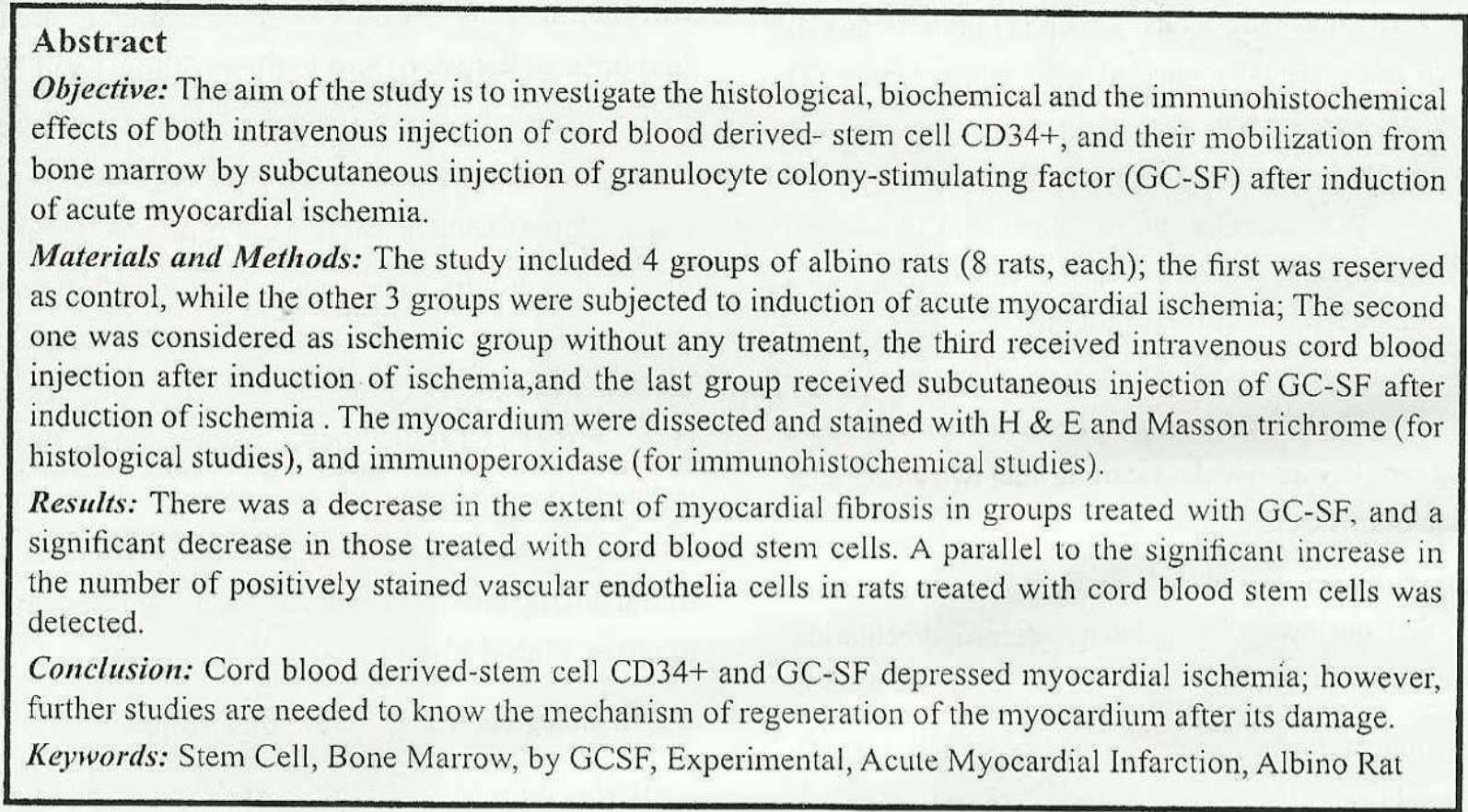

\section{Introduction}

Coronary artery disease is the most common form of heart disease and is the leading cause of death. This condition occurs when the arteries and the smaller vessels that supply oxygen-rich blood to the heart muscle are blocked by blood clots $^{(1)}$. During total or near-total occlusion of coronary artery, perfusion of ischemic myocardium occurs through collateral circulations. Acute coronary occlusion produces no infarction in individuals with a well developed network of collaterals, whereas individuals who lack such network of collaterals develop rapid and complete infarction upon acute coronary occlusion ${ }^{(2)}$. Management of myocardial ischemia is either a medical or surgical procedure. But there are adult subjects who have severe coronary artery disease, and are not suitable candidates for conventional procedures. In those subjects, stem cell therapy is the gold standard procedure ${ }^{(3)}$. Adult stem cell therapy for heart disease creates new blood vessels that improve blood flow to the heart as well as generate new tissue in the heart muscle itself ${ }^{(4)}$. These stem cells will be able to stimulate the growth of new blood vessels to bring more blood and oxygen to the heart muscle, so that patients will have a better quality of life and less chest pain ${ }^{(5)}$. Stem cells not only differentiate into contracting cardiac myocytes but also secrete cytokines such as vascular endothelial growth factor that promote angiogenesis ${ }^{(6)}$. Granulocyte Colony-Stimulating Factor (G-CSF) is a hormone, glycoprotein, growth factor or cytokine produced by different tissues to stimulate the bone marrow to produce granulocytes and stem cells. G-CSF then stimulates the bone marrow to pulse it out of the marrow into the blood. G-CSF is produced by endothelium, macrophages, 
and a number of other immune cells ${ }^{(7)}$. Local GCSF administration into ischemic tissue increased capillary density and provided a functional vasculature and contributed to neo-vascularization of ischemic tissue ${ }^{(8)}$.

\section{Materials and Methods}

Experimental design: Adult female albino rats (No. $=$ $32 ; 150-300 \mathrm{~g}$ ) were equally divided into the following four groups, each containing 8 rats: Group (1) (control group), in which rats were only injected with saline. Group (2): myocardial ischemia was induced by subcutaneous injection of Isoprinosine hydrochloride. Group (3): rats were injected with stem cells (a dose of 106 umbilical cord blood stem cellrat, injected intravenously in the tail vein of the rat after one month of induction of myocardial ischemia. Group (4): rats were injected with granulocyte-colony stimulating factor (NEUPOGEN) subcutaneously in a dose of 100 micro gram $k \mathrm{~kg}$ each day for five days starting after two weeks after induction of myocardial ischemia.

Induction of myocardialischemia: Myocardial ischemia was carried out by injecting Isoprenaline hydrochloride, subcutaneously in a dose of $85 \mathrm{mglkg}$ daily for two weeks.

Isolation of low density Mononuclear Cells (MNC): Cord blood was collected in presence of anticoagulant and was diluted 1:1 in isolation buffer. Diluted cord blood (7 $\mathrm{ml}$ ) was transferred on to $3 \mathrm{ml}$ Ficoll and was centrifuged $20 \mathrm{~min}$ at $800 \mathrm{~g}$ (Figure 1). The interface which contains the low density mononuclear cells was collected and suspended in equal volume of isolation buffer and was centrifuged 20 $\min$ at $500 \mathrm{~g}$.

Positive selection of CD34+cells: The cells were resuspended thoroughly with a narrow tip pipette to prevent cells from aggregating before adding them to the beads, then incubated for 30 minutes. The tube was placed in a DYNAL MPC for 2 minutes to separate Dynabeads M-450 CD34rosetted cells from non target cells and the isolation buffer was added to the height of the magnet.

Transplantation of HUCB stem cells: After preparation of UCB stem cells, a dose of 106 UCB stem cells per rat were injected IV in the dorsal tail vein.

\section{Results}

\section{Histological and histopathological results:}

Examination of sections from the control group, showed normal cardiac muscles (Figure 2). Myocardial section from the ischemic group showed that many histopathological changes were present in the form of severe and massive fibrosis among and in between myocardial fibers (Figure 3), focal areas of inflammatory infiltration, and scattered areas of hemorrhage between muscle fibers (Table I and Figure 4). Myocardial section from the ischemic rats treated with granulocytes colony-stimulating factor,showed regenerative changes There were moderate focal areas of fibrosis among and in between myocardial fibers in 50\% of cases (Table I and Figure 5). Myocardial section from the ischemic rats treated with umbilical cord blood CD34+derived stem cells revealed regenerative changes and restoration of the functional unit of the cardiac tissue.focal areas of fibrosis were found amang and inbetween myocardial fibers in 20\% of cases. (Table 1 and Figure 6).

\section{Hematological results of the study group:}

It was noticed that there were significant changes in the hematological parameters in all study groups. There was a significant increase in serum $\mathrm{CK}$ and $\mathrm{CK}$ (MB) in the ischemic groups Table (II). Aignificant improvement in hematological parameters was noticed in the group treated with umbilical cord blood stem cells $(\mathrm{p}<0.05)$ and slight decrease in serum CK \& CK $(\mathrm{MB})$ in the group treated with granulocyte colonystimulating factor.

\section{Results of inmunohistochemistery:}

Immunostaining of VEGF in myocardial sections showed the following changes: In the control group, there was no VEGF expression in $100 \%$ of cases (Figure 7). In the ischemic group, there was mild overexpression of VEGF. Moderate VEGF over-expression was noticed in rats treated with GC-SF. Rats treated with umbilical cord blood stem cells showed intense over-expression of VEGF with marked proliferation of vascular endothelial cells (Figure 8). 

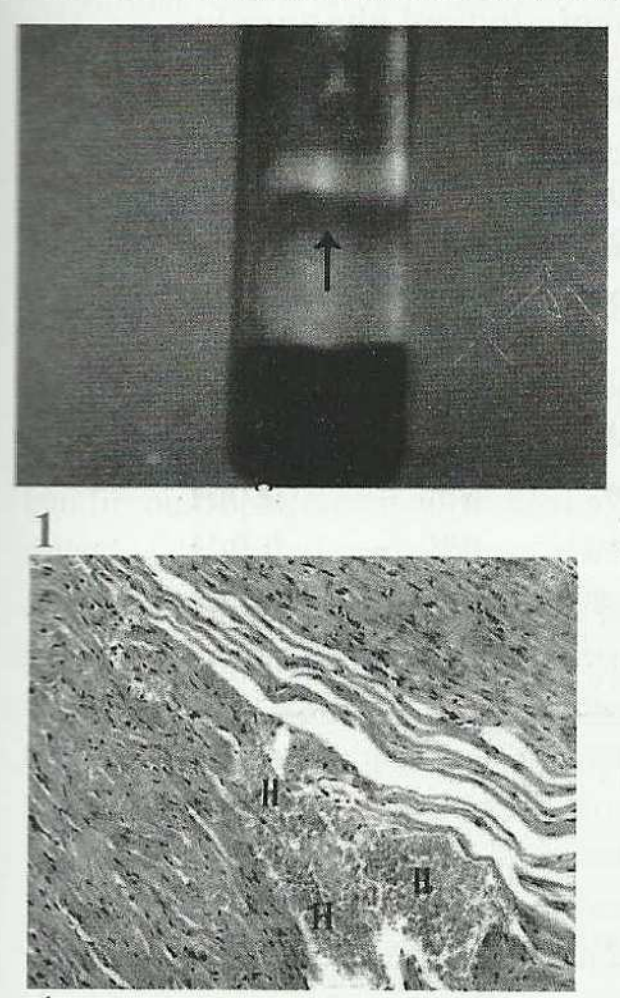

4

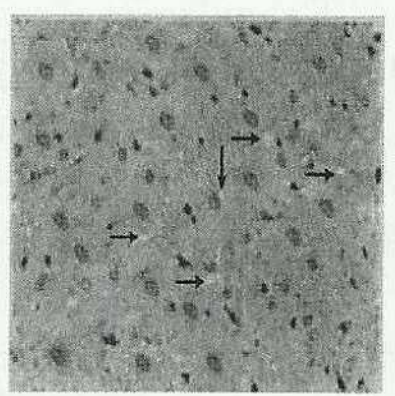

7

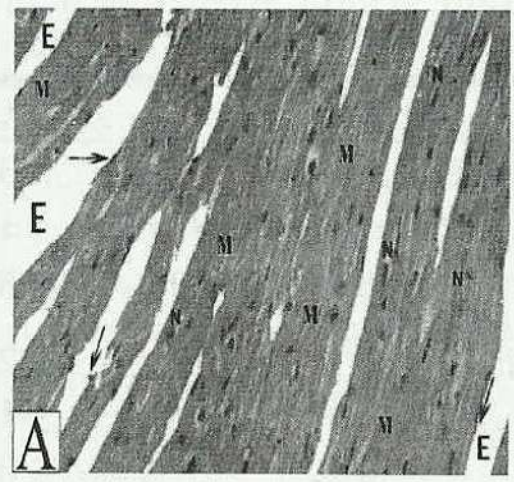

2

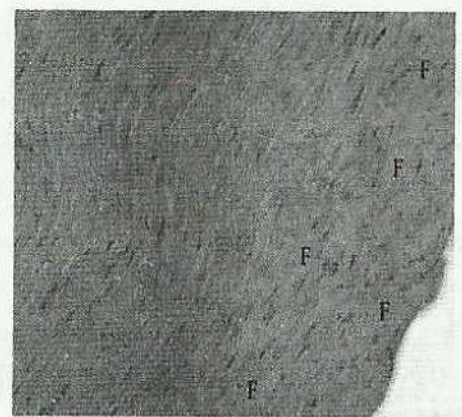

5

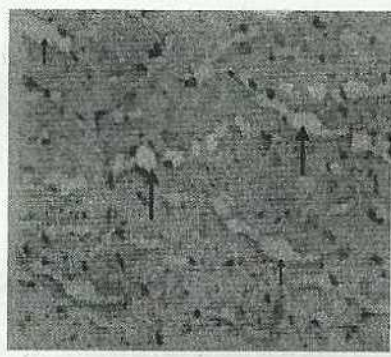

8

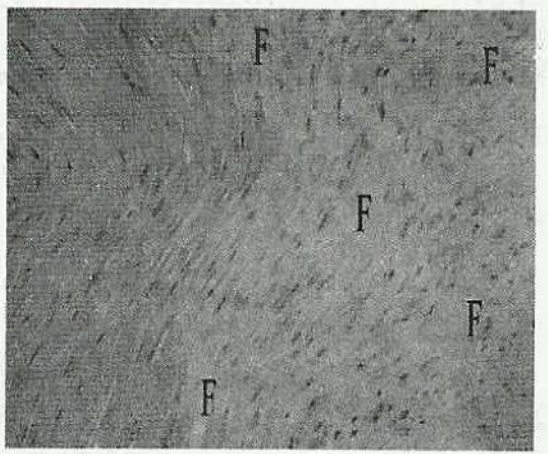

3

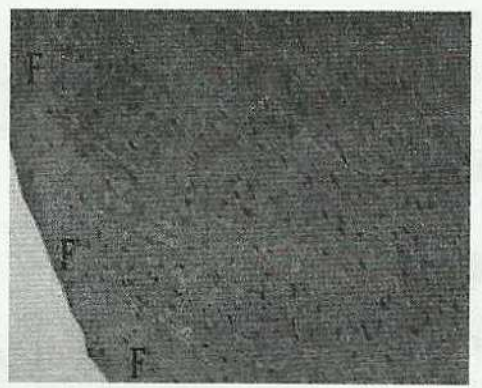

6

Figure 1: Isolation of low density Mononuclear Cells (MNC). (The arrow refered to the buffy coat).

Figure 2: Photomicrograph myocardial longitudinal section from control group showin£ branched and anastomozing myocardial fibers $(\mathrm{M})$, with prominent central vesicular nucleu: $(\mathrm{N})$. Myocardial fibers are separated from each other by endomysium (E), a vascular loos connective tissue spaces with scattered fibroblasts (The arrow) (A: H\& E X400).

Figure 3: Photomicrograph myocardial longitudinal section from the ischemic grour showing massive fibrosis $(\mathrm{F})$ along and in between muscle fibers (H\&E X400).

Figure 4: Photomicrograph myocardial longitudinal section from the ischemic grour showing multiple focal areas of hemorrhage $(\mathrm{H})(\mathrm{H} \& \mathrm{E} X 400)$.

Figure 5: Photomicrograph myocardial longitudinal section from the ischemic group treatec with granulocyte colony-stimulating factor showing moderate fibrosed $(F)$ areas along and ir between muscle fibers (H\&E X400).

Figure 6: Photomicrograph myocardial longitudinal section from the ischemic group treatec with cord blood CD+34 derived stem cells showing small areas of fibrosis (F) along and ir between muscle fibers (H\&E X400).

Figure 7: Photomicrograph myocardial section from control group showing negativs cytoplasmic immunostaining of vascular endothelial cells for VEGF(The arrow. (Immunostain $\mathrm{x} 400$ ).

Figure 8 : Photomicrograph myocardial section from rats treated with umbilical cord blood CD34+ derived stem cells showing intense expression of VEGF with marked vascular endothelial cells proliferation (The arrows) (Immunostain X400). 
Table (1): Comparison between four groups according to morphological changes in histological sections

\begin{tabular}{|c|c|c|c|c|c|c|}
\hline \multicolumn{2}{|c|}{ Morphological Changes } & G1 & G2 & G3 & G4 & P value \\
\hline \multirow{2}{*}{\multicolumn{2}{|c|}{$\begin{array}{l}\text { Preserved Myocardial architecture } \\
\text { No fibrosis }\end{array}$}} & $100 \%$ & $0 \%$ & $30 \%$ & $10 \%$ & \multirow[t]{3}{*}{0.001} \\
\hline & & $100 \%$ & $0 \%$ & $12 \%$ & $10 \%$ & \\
\hline & Mild fibrosis & $0 \%$ & $20 \%$ & $58 \%$ & $25 \%$ & \\
\hline \multirow{4}{*}{$\begin{array}{l}\text { Myocardial } \\
\text { Fibrosis } \\
\text { Hemorrhage } \\
\text { Pyknosis }\end{array}$} & Moderate fibrosis & $0 \%$ & $15 \%$ & $20 \%$ & $50 \%$ & \multirow{4}{*}{$\begin{array}{l}0.001 \\
0.001 \\
0.001\end{array}$} \\
\hline & Marked fibrosis & $0 \%$ & $65 \%$ & $10 \%$ & $15 \%$ & \\
\hline & & $0 \%$ & $57.1 \%$ & $0 \%$ & $0 \%$ & \\
\hline & & $0 \%$ & $65.6 \%$ & $0 \%$ & $0 \%$ & \\
\hline \multicolumn{2}{|c|}{ Inflammatory Infiltration } & $0 \%$ & $42.9 \%$ & $0.3 \%$ & $0.2 \%$ & 0.001 \\
\hline \multicolumn{2}{|c|}{ Chromatin Margination } & $0 \%$ & $44.4 \%$ & $0 \%$ & $0 \%$ & 0.001 \\
\hline
\end{tabular}

Mild fibrosis $20 \%$ *

Moderate fibrosis $50 \%$. $^{*}$

*Marked fibrosis $65 \%$.

Table (2): Hematological indices of rats in all studied groups

\begin{tabular}{|l|l|l|l|l|}
\hline $\begin{array}{l}\text { Hematological } \\
\text { parameters }\end{array}$ & control & $\begin{array}{l}\text { MI } \\
\text { group }\end{array}$ & $\begin{array}{l}\text { MI } \\
\text { Cord blood stem } \\
\text { cells treated group }\end{array}$ & $\begin{array}{l}\text { MI } \\
\text { Granulocyte } \\
\text { colony-stimulating } \\
\text { factor treated group }\end{array}$ \\
\hline $\begin{array}{l}\text { CK-MB } \\
\text { Mean (U/L) } \pm \text { SD }\end{array}$ & $69.2 \pm 11.1 \#^{*}$ & $307.1 \pm 29.5$ & $169 \pm 15^{*}$ & $187.7 \pm 20^{*}$ \\
\hline $\begin{array}{l}\text { CK } \\
\text { Mean (U/L) } \pm S D\end{array}$ & $46.4 \pm 21 \#^{*}$ & $380 \pm 40$ & $280 \pm 30^{*}$ & $298 \pm 32^{*}$ \\
\hline
\end{tabular}

$\mathrm{N}=8, \mathrm{P}<0.05$ considered significant .

\# Statistical significance compared to other study groups

* Statistical significance compared to MI group.

Discussion

Cord blood transplantation is primarily performed in children, rather than in adults due to the lower number of hematopoietic progenitor cells obtained from the small volume of single cord blood collection ${ }^{(21)}$. Circulating bone marrow stem cells can differentiate into cardiomyocytes in regenerative heart after acute myocardial ischemia remains unclear ${ }^{(20)}$.

Recently, it has been found that some of the hematopoietic growth factors which proliferate, differentiate and mobilize hematopoietic progenitor cells from bone marrow to peripheral blood can stimulate myocardial regeneration after induction of acute myocardial ischemia either by endogenous mechanisms through their adhesion receptors receptors or by mobilization of hematopoietic stem cells ${ }^{(9)}$.

Histological examination revealed that rats receiving isoprenaline hydrochloride without stem cells treatment (Group 2) showed preserved myocardial architecture but with varying degree of cells changes in the form of myocardial fibrosis (65\%), focal areas of hemorrhage (57.1\%), pyknosis of the nuclei $(65 \%)$, chromatin margination (44.4\%), and focal areas of inflammatory infiltrate $(42.9 \%)$ in all rats of the group. This is similar to Orlic et al. ${ }^{(7)}$ who found that areas of myocardial fibrosis and necrosis in rats receiving isoprenaline hydrochloride were significantly more than stem cells treated rats. 
Similar results were obtained by Kocher et al. ${ }^{(8)}$ who studied the effect of G-CSF on myocardial repair after its damage and reported that myocardial remodeling is a major cause of progressive heart failure and death after myocardial infarction. Although neoangiogenesis within the ischemic tissue is an integral component of the remodeling process, the capillary network is unable to support the greater demands of the hypertrophied myocardium, resulting in progressive loss of viable tissue, infarct extension and fibrous replacement. Orlic et al., ${ }^{(7)}$ reported that, injection of granulocyte colony stimulating factor (G-CSF) mobilized adult-human CD34+cells with phenotypic and functional properties of embryonic hemangioblasts can stimulate neoangiogenesis in the infarct vascular bed, thus preventing myocyte apoptosis and reducing collagen deposition and scar formation after experimental myocardial infarction. Primitive bone marrow cells mobilized by stem cell factor and granulocyte-colony stimulating factor, home to infaret regions, replicate, differentiate and ultimately promote myocardial repair. In the presence of an acute myocardial infarct, cytokine-mediated translocation of $\mathrm{BMC}$ resulted in significant tissue regeneration 27 days later. Bone marrow cells injected or mobilized to the damaged myocardium behave as cardiac stem cells with remarkable plasticity, giving rise to myocytes, endothelial cells, and smooth muscle cells.

The absence of rejection to UCB stem cells may be due to the unique immunological properties of both stem cells and non- stem cell components of the cord blood. It may be possible to utilize allogenic cells for regenerative applications without needing to fully compromise the recipient immune system $^{(10)}$.

In the current study, the degree of cardiac function and myocardial fibrosis were better in both group (3) and (4) but still better in group (3) than in group (4). $\mathrm{CK}$ and $\mathrm{CK}(\mathrm{MB})$ were significantly lower in group (3) rats and in group (4) rats compared to that in group (2). However, CK and CK (MB) levels are less in group (3) than group (4) when compared with group (1). Caspi et al. ${ }^{(10)}$ found that the levels of creatine kinase in rats treated with stem cells transplantation after induction of acute myocardial ischemia were significantly lower compared to those of only myocardial ischemia group without stem cells transplantation. One mechanism of action by which cells provide tissue protection and repair may involve paracrine factors, including cytokines and growth factors, released from transplanted stem cells into the surrounding tissue. These paracrine factors have the potential to directly modify the healing process in the heart, including neovascularization, cardiac myocyte apoptosis, inflammation, fibrosis, contractility, bioenergetics, and endogenous repair. Therefore, they hypothesized that transplantation of UCB stem cells can promote proliferation of the functional myocardium of the host. Also our results go with the result of Malouf et al. ${ }^{(11)}$, who demonstrated that, stem cell lines that are neither of embryonic origin nor committed to a muscle lineage will engraft in the adult heart in vivo and differentiate into well-organized mature cardiac myocytes. The adult heart micro-environment expresses the appropriate signals that allow the exit of these extra cardiac liver cells from their stem-cell state and differentiation into myocytes. This raises the possibility that adult-derived human stem cells can be isolated from a patient, propagated in culture, and used to support the patient's diseased heart.

The present study showed that the infusion of CD34+ stem cells into the myocardium might initiate endogenous myocardial tissue repair that opposes the injury inflicted by ischemia. Our results were identical to Carmeliet et al. ${ }^{(12)}$ who had the same finding that, growth factors binding to the VEGF receptor are important mediators of stem-cell recruitment and mobilization angiogenesis, and is the major mediator of endothelial cell proliferation.

\section{References}

1. Chon PF. Silent myocardial ischemia: classification, prevalence, end prognosis. Am J Med; 1985, 79(3A): 2-6.

2. Mosca L, Banka CL, Benjamin EJ et al. Evidence-based guidelines for cardiovascular disease prevention in women. Circulation; 2007, 49:1230-1250.

3. Boersma E, Mercado N, Poldermans D, Gardien M, Vos J, Simoons ML. Acute myocardial infarction. Lancet; 2003, 361(9360):847-58.

4. Braunwald M. Management of patients with unstable angina and ST-segment elevation MI: A report of the ACC/ AHA Task Force on Practice Guidelines. November 2002.

5. Beltrami AP, Urbanek K, Kajstura J, Yan SM, Finato N, Bussani R, et al. Evidence that human cardiac myocytes divide after myocardial infarction. $\mathrm{N}$ Engl J; 2001, 344: 1750-1757. 
6. Jackson, K.A., Majka, S.M., Wang, H., Pocius, J., Hartley, C.J., Majesky, M.W., Entman, M.L., Michael, L.H., Hirschi, K.K., and Goodell, M.A. Regeneration of ischemic cardiac muscle and vascular endothelium by adult stem cells. J. Clin. Invest;2001, 107: 1-8.

7. Orlic D., Kajstura J., Chimenti S., Jakoniuk I., Anderson SM., Li B., Pickel J., McKay R., Nadal- Ginard B., Bodine DM., Leri A., Anversa P. Bone marrow cells regenerate infracted myocardium. Nature;2001, 410: 701705.

8. Kocher, A.A., Schuster, M.D., Szabolcs, M.J., Takuma, S., Burkhoff, D., Wang, J., Homma, S., Edwards, N.M., and Itescu, S. Neovascularization of ischemic myocardium by human bone-marrow-derived angioblasts prevents cardiomyocyte apoptosis, reduces remodeling and improves cardiac function. Nat. Med.; 2001,7: 430-436.

9. Etzion S, BattlerA., Barbash IM, et al. Influence of embryonic cardiomyocyte transplantation on the progression of heart failure in a rat model of extensive myocardial infarction. $J$ Mol Cell Cardiol; 2001, 33: 1321-1330
10. Caspi O., Huber I., Kehat I., et al. Transplantation of human embryonic stem cell-derived cardiomyocytes improves myocardial performance in infarcted rat hearts $\mathrm{J}$ Am Coll Cardiol; 2007, 50:1884-93.

11. Malouf NN, Coleman WB, Grisham JW et al. Adult derived stem cells from the liver become myocytes in the heart in vivo. Am J Phatol; 2001, 158: 1929 - 1935.

12. Carmeliet P., and Jain, R.K. Angiogenesis in cancer and other diseases. Nature; 2002,407: 249-257.

\section{Correspondence to}

\section{Gamal Mohamed Abdl-Rahman,MD}

Department of Anatomy

Faculty of Medicine

Suez Canal University

E-mail:Abdulrahman.200@hotmail.com

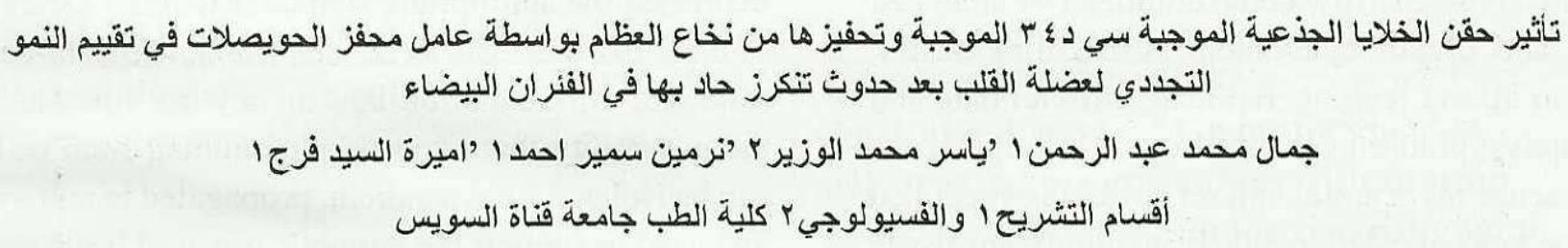

الهذف من البحث: معرفة التغير ات التي تحدث في خلايا القلب والناتجة عن قصور في الثرايين التاجية ونقص وصول الأكسجين بهاو وتأثبر

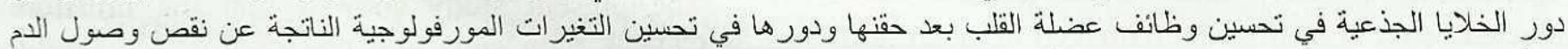

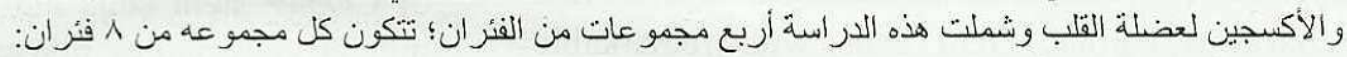

مجمو عة ضابطة, مجموعة تجريبية تم فيها حدوث فقر دم وموضعي في عضلة القلب عن طربي حقن عقار الايزوبرينالين تحت الجلا

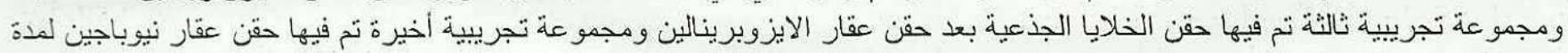

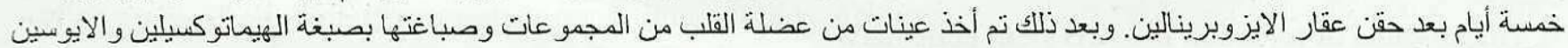

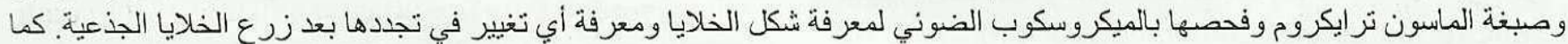
تم اخذ عينات من دم الفئران لقياس إنزيمات وظائف القلب في كل المجمو عات, كما تم قياس مستقبلات عامل منشط ألا و عيه الدموية بنسيج القلب بأستخدام المضاد المناعي له

وكانت النتائج هي تحسن وظائف القلب لادي الفنر ان مما أدي إلي انخفاض نسبة إنزيمات القلب التي كانت قد ارتفعت نتيجة لحدوت تنكرز

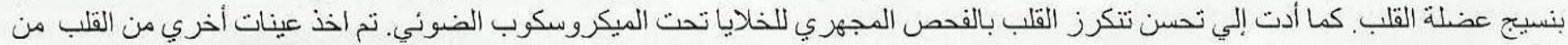
المجمو عات السابقة وفيها نم قياس عامل منشط الاو عيه الدموية في نسيج القلب باستخدام المضاد المناعي له بطريقه القياس الكيميائي للعامل بالا نسجه وقد لوحظ عدم ظهور هذا العامل في المجو عة الضابطة وفي المجهوعة التجريبية الثانية لوحظ زيادة ظهور عامل منشط الاو عيه الدموية

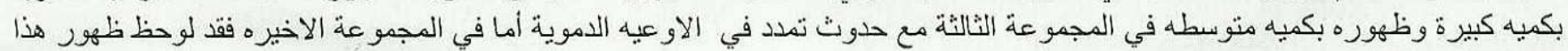

